\title{
リングせん断試験のせん断面と地すべり面における微視的構造の比較 Comparison of microscopic structure in shear plane of the ring shear test and slip surface
}

\author{
村尾英彦(a)，釜井俊孝卢，野坂 徹 ${ }^{\mathrm{a})}$ \\ Hidehiko MURAO, Toshitaka KAMAI and Toru NOZAKA
}

\begin{abstract}
Soil has a structure in which various particles are arranged as a result its geological history. Therefore, by determining the current structure of the soil, it is possible to estimate the stress history of the soil and to predict how it will behave. In particular, the orientation of clay particles is a notable feature in landslide clay that has experienced large deformation. Accordingly, the particle orientation should be useful for estimating movement direction, and stress state. In this study, with the aim of deepening understanding of the microscopic structure of landslide clay, the formation process of landslide clay in the landslide zone of a Tertiary formation was investigated by using the ring shear test to compare the shear plane and the slip surface of an undisturbed specimen. Our investigation found that (1) the microscopic structure of shear planes in a residual strength state due to large deformation exhibits slickensides and striations, (2) the shear layer is formed from a folium of peds arranged parallel to the shear plane, and (3) the shear layer has a fully oriented structure differing from that of the dispersed structures in the local area.

Key words : landslide, slip surface, failure, residual strength, soil structure

\section{和文要旨}

土は，土粒子が過去に受けた履歴の結果として，配列した構造を持っている。よって，現在の土の微視的構造を知ることにより， その土が経験した応力履歴および，今後の挙動を推定可能であると考える。特に，大変形を経験した地すべり粘土においては，粘 土粒子の配向が顕著である。よって, 地すべり粘土の配列程度から, 変動方向や応力状態の推定ができる可能性が高い。本研究で は，地すべり粘土の微視的構造に関する理解を深めることを目的として，新第三系の地すべり粘土の生成過程に関する考察を行っ た。その検討から, 大变形を経験し, 残留強度状態にあるせん断面の微視的構造の特徵として, 鏡肌を呈し, 条線が見られること, せん断面周辺には，せん断面と平行にペッドが配列した構造を持つ薄層が生成され，せん断層を形成していること，せん断層は， 完全配向構造となっており，周辺の分散構造とは異なる構造を持つことが明らかとなった。

キーワード：地すべり, すべり面, 破壞, 残留強度, 土の構造
\end{abstract}

\section{1.はじめに}

地すべり粘土は，すべり面付近に発達した，地すべり 土塊の変動に決定的な役割を果たす弱層である。新第三 系の地すべりなどにおいて確認されることが多く，一般 的に，数 $\mathrm{mm}$ 数 $\mathrm{cm}$ の厚さを持つとされている ${ }^{1)}$ 。すべ り面に抢いては，鏡肌が認められることが多く，X線回 折を行うと，母岩の性質に依存した粘土鉱物が多く含ま れている。特に新第三系の地すべりに扔いては, 主要粘 土鉱物としてスメクタイトが多く含まれていることが知 られている。地すべり粘土は, 変位量が増加するに伴い, 擦痕状，粘土混じり礫状，砂混じり粘土状，粘土状とい う変遷を示し，粘土分が増加する2)。また，変位の増加 に伴って, 強度は完全軟化強度から残留強度へと低下寸 る。日本国内の新第三系の再滑動型地すべりは，大変形 を経験しているものが多いことから，すべり面の強度は， 大半が残留強度状態にあると考えられている。また, 残 留強度状態にある, 多数の地すべり面の強度に関する研 究汭や，すべり面の地質的特徵及び，構造物性，強度等 の実態について整理された報告4が存在し, 研究が進め

* 連絡著者/corresponding author

a ) 株式会社村尾地研

Murao Chiken Co., Ltd

Murao Chiken Co., Ltd
T939-8262 富山市塚原150

150 Tsukahara, Toyama city, Toyama Prefecture, Japan

b) 京都大学防災研究所

Disaster Prevention Research Institute, Kyoto University
られている。

主として 2 次元断面安定解析が行われる実務において は, 残留強度状態にあるすべり面の, 強度定数として, リングせん断試験より得られた内部摩擦角 $\phi_{\mathrm{r}}^{\prime}$ と, 滑動状 態から設定した安全率から，調査時の情報から評価する ことが困難な, すべり面のせん断抵抗力以外の抵抗力 (地 形や, 地すべり頭部, 側部, 末端部の縁端効果など）を 含めた，安定解析用の粘着力 $\mathrm{c}_{\mathrm{inv}}$ (この值は，土粒子と 吸着水の物理化学的作用による粘着力とは異なるパラ メータ）を逆算する方法 ${ }^{5}$ などが，経験的に有効な手法 として提案されている。

一方で，地すべり粘土の生成過程や，粘土の微視的構 造と，力学的特性の関係には，未だ不明なことが多い。 これらの関係を解明するには，地すべり粘土を微視的な 視点から考察し, 構造の変化と応力状態の対応を明らか にすることが必要である。

本研究は, 地すべり粘土の微視的構造に関する理解を 深めることを目的として, 新第三系の地すべり地で採取 した，不攪乱試料中の地すべり粘土の微視的構造と，リ ングせん断試験におけるせん断面の微視的構造を比較し, 地すべり粘土の構造と力学的特性に関する考察を報告す るものである。 


\section{2. 試料について}

試料を採取した地すべり地周辺の地質は，新第三系中 新統砂岩泥岩互層で, 10 30 程度の傾斜を持つ流れ盤 構造の斜面である。地すべりは融雪期や，豪雨に伴い滑 動を繰り返す再滑動型地すべりである。砂岩は，凝灰質 で泥岩や凝灰岩粒を一部に含み，泥岩は緻密で固化して いる。また，新第三系の泥岩が主体であることから，風 化耐性が低く，地すべり地周辺での露頭は風化し，容易 に剥落する状態であるものが多い。

地すべりブロックにおける動態観測，コア観察，地下 水検層結果より, 深度 $10.0 \mathrm{~m}$ 地点の風化泥岩と強風下泥 岩の境界にすべり面の存在を判定した。この地点で採取 した不䚓乱試料において確認したすべり面を図ー 1 に示 す5)。すべり面には鏡肌が形成されており，粘土化した 層の厚さは $2 \mathrm{~mm}$ （すべり面を挟んで $4 \mathrm{~mm}$ ）程度であ る。また，目視において，地すべりの移動方向に平行な 条線が確認でき, 親指の爪が貫入可能な程度の硬さである。

\section{3. 物理的性質}

リングせん断試験に用いた試料には，図－2に示すよ うに，すべり面を含んだ上位 $30 \mathrm{~cm}$ 区間の強風化泥岩を

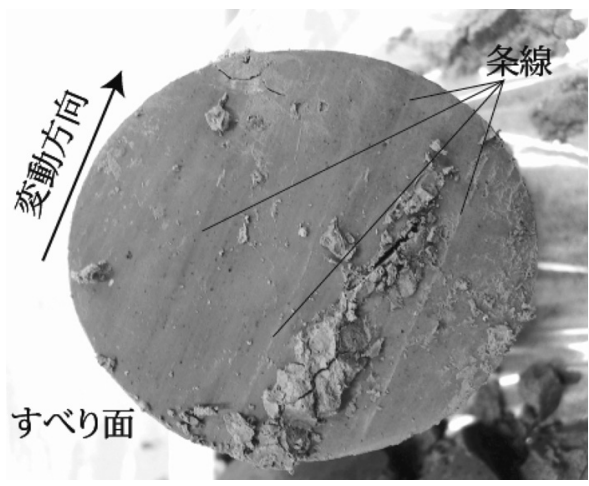

図一 1 すべり面 ${ }^{5)}$

Fig. 1 Slip surface ${ }^{5)}$

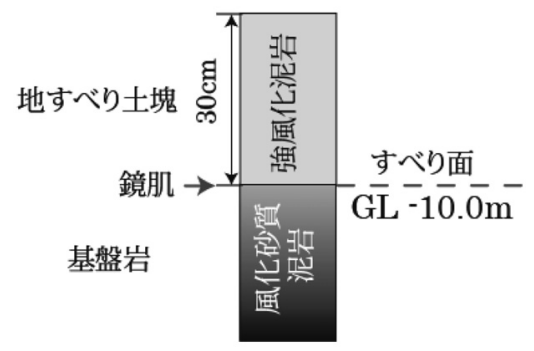

図一 2 試料採取箇所 ${ }^{5}$

Fig. 2 Sampling locations ${ }^{5)}$
用いており，既報5においてすべり面上位の風化泥岩部 分より採取した試料を混合した試料である。試料の物理 的性質を表- 1 に，粒径加積曲線を図- 3 に示す。試料 の $98.5 \%$ はシル粒径 $(75 \mu \mathrm{m})$ 以下で, $50 \%$ は粘土粒径 （ $5 \mu \mathrm{m} ）$ 以下である。また，塑性指数 $\mathrm{I}_{\mathrm{p}}$ が $56.8 \%$ と高塑 性を示し，活性度A $>1.25$ となることから，有機コロイ ドを含む活性粘土（スメクタイト質土）に分類される。 なお，物理試験は，リングせん断試験用の供試体を作成 する前の，十分に摚拌した試料を用いて実施しており， 各上載圧毎に作成した供試体の代表的な值である。

\section{4. 力学的性質}

すべり面粘土の強度定数を求めるために，リングせん 断試験を実施した。図ー4にせん断応力 $\tau$ 一せん断変位 D関係を，図ー 5 にクーロンの破壊規準を示す。なお， リングせん断試験に用いた供試体は，以下の手順で作成

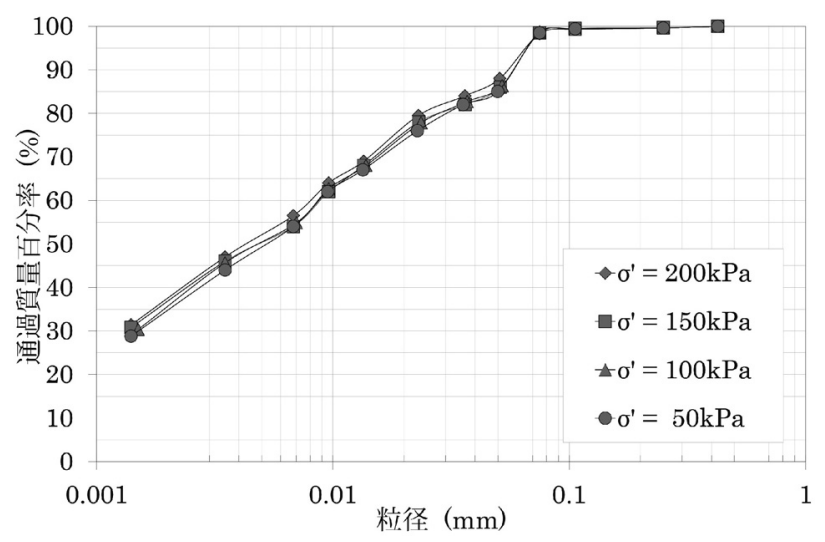

図一３リングせん断試験試料の粒径加積曲線

Fig. 3 Grain size accumulation curve of the ring shear test samples

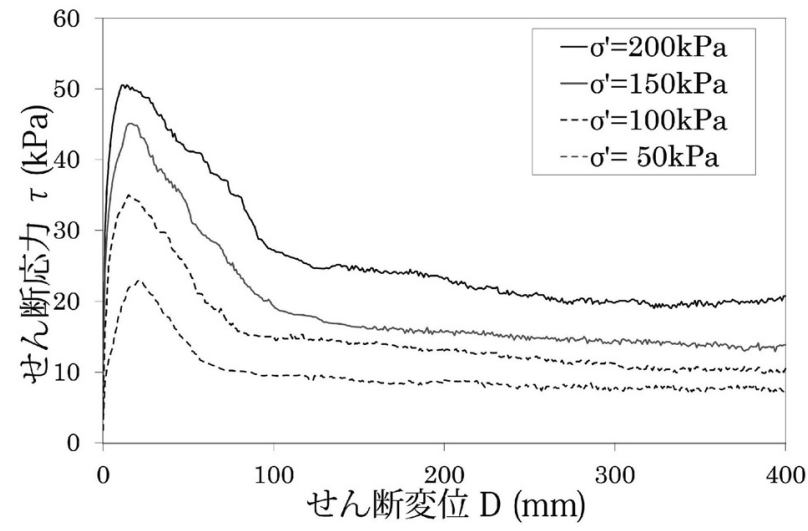

図ー4 リングせん断試験結果

Fig. 4 Ring shear test results

表一 1 すべり面粘土の物理的性質

Table 1 Physical properties of the slip surface clay

\begin{tabular}{ccccccccc}
$\begin{array}{c}\text { 液性限界 } \\
\mathrm{w}_{\mathrm{l}}(\%)\end{array}$ & $\begin{array}{c}\text { 塑性限界 } \\
\mathrm{w}_{\mathrm{p}}(\%)\end{array}$ & $\begin{array}{c}\text { 塑性指数 } \\
\mathrm{I}_{\mathrm{p}}(\%)\end{array}$ & $\begin{array}{c}\text { 細粒分含有率 } \\
\mathrm{Fc}(\%)\end{array}$ & $\begin{array}{c}\text { 活性度 } \\
\mathrm{A}\end{array}$ & $\begin{array}{c}\text { 土粒子の密度 } \\
\rho_{\mathrm{s}}\left(\mathrm{g} / \mathrm{cm}^{3}\right)\end{array}$ & 砂分 $(\%)$ & シル下分 $(\%)$ & \begin{tabular}{c} 
粘土分 $(\%)$ \\
\hline 105.3
\end{tabular} \\
\hline 48.5 & 56.8 & $\mathbf{9 8 . 5}$ & 1.42 & 2.60 & 1.5 & 48.5 & 50 \\
\hline
\end{tabular}


した。

1. 採取した粘土に, 蒸留水を加えながら $425 \mu \mathrm{m}$ の ふるいで裏ごしを行う。

2. 含水比 $200 \%$ とした上で十分に摚拌する。

3 . 一次元圧密条件下で, せん断時の上載圧で予圧密 を行う。

4. 压密が進行し, 24 時間の垂直変位がゼロとなった 時点で圧密完了とする。

5 . 外径 $150 \mathrm{~mm}$, 内径 $100 \mathrm{~mm}$, 高さ $20 \mathrm{~mm}$ の中空円 筒型に整形し，試験機にセットする。

なお, 4.の圧密完了条件は, 圧密試験で用いられる, $3 \mathrm{t}$ 法による圧密打ち切りを十分に満たしている。

試験機は, ビショップ型試験機(6)に改良を加えたもの7) を使用している。試験条件は，上載圧一定，ひずみ制御 方式，せん断速度 $0.015 \mathrm{~mm} / \mathrm{min}$ おょび，排水条件とし ている。また，供試体は正規圧密粘土 $(\mathrm{OCR}=1.0)$ で ある。

表ー 2 に，リングせん断試験より得られた，完全軟化 強度の強度定数 ( $\left.\mathrm{cfs}^{\prime}, \phi \mathrm{fs}^{\prime}\right)$ および, 残留強度の強度定 数 $\left(\mathrm{cr}^{\prime}, \phi \mathrm{r}^{\prime}\right)^{8)}$ を示す。残留強度の内部摩擦角 $\phi \mathrm{r}^{\prime}\left(^{\circ}\right)$ は, 既報)においては, $\phi \mathrm{r}^{\circ}=4.42,4.66 .4 .78\left(^{\circ}\right)$ となり, 今 回の試験でも，ほぼ同様な值が得られている。完全軟化 強度, 残留強度を求めた際の相関係数は, 完全軟化強度 で 0.99 , 残留強度で 0.97 と, 共に良好である。

試験より得られた, 残留強度状態における粘着力は, $\mathrm{cr}^{\prime}=1.66 \mathrm{kPa}$ となっている。理論的には, 残留強度状態 となった供試体は，せん断面を境界として分離している

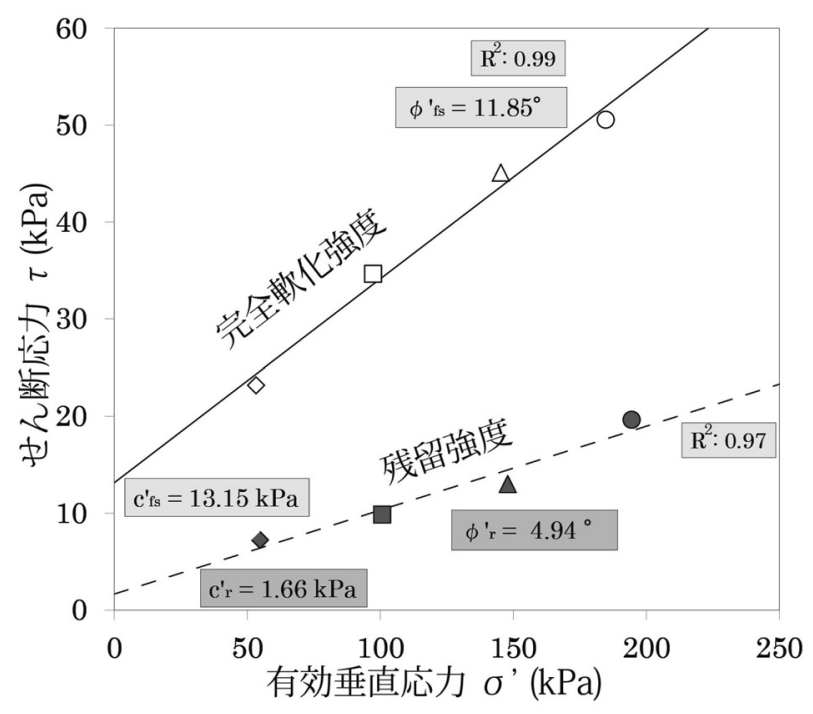

図一 5 Coulombの破壊規準

Fig. 5 Coulomb's failure criterion

表ー 2 リングせん断試験よる強度定数

Table 2 Strength parameters from the ring shear test 完全軟化強度 残留強度

\begin{tabular}{cccc}
$\mathrm{Cfs}^{\prime}(\mathrm{kPa})$ & $\phi \mathrm{fs}^{\prime}($ degree$)$ & $\mathrm{cr}^{\prime}(\mathrm{kPa})$ & $\phi \mathrm{r}^{\prime}$ (degree) \\
\hline 13.15 & 11.85 & 1.66 & 4.94 \\
\hline
\end{tabular}

ことから，粘着力はゼロであると考えられる。よって， 今回得られた，極めて小さい值であるcr'=1.66kPaは， 試験機の摩擦等が原因で生じた系統誤差であると考える。

残留強度の定義は, 排水せん断あるいは, 定圧せん断 に扔いて，せん断抵抗がピーク值を超え，漸次低下して， 究極的な定常せん断状態に達した時の值である。リング せん断試験において, 残留強度に至っているかを判断す るには，上記の定義を満たし，強度がほぼ一定の值に収 束した際とし, 今回の検討では, せん断変位 $5 \mathrm{~mm}$ に対し て, せん断応力の変動幅が $1 \mathrm{kPa}$ 以内に収束した場合と した。これらは，垂直応力の差異に関わらず同様である。 多くの地すべりに見られる, すべり面の大変位を再現 するために, 垂直応力 $\sigma^{\prime}=200 \mathrm{kPa}$ 条件下において, せ ん断変位 $\mathrm{D}=1000 \mathrm{~mm}$ 経た, 供試体のせん断面（以下， せん断面と記す）を図-6に示す。図-6に抒いて，せ ん断面にはすべり面（図-1）と同様に，鏡肌が形成さ れている。また，せん断方向には，同心円状の条線を確 認することができる。せん断面と，不攪乱試料中のすべ り面（以下，すべり面と記す）を目視で比較すると, 光 沢や色調は同程度である。一方で, 条線の数に関しては, せん断面の方が多い。

\section{5. 主要粘土鉱物の評価}

鉱物組成，粘土鉱物を同定するために，粉末X線回折 法による分析 "行った。分析方法は，不定方位回折に よる全組成鉱物の同定である。図 - 7 に地すべり粘土(図 - 1 に示したすべり面より試料採取）のX線回折チャー 卜を，図-8にリングせん断試験後（図-6に示したせ ん断面より試料採取）の，供試体せん断面のX線回折 チャートを示す。なお，分析機器には(株)リガク製ガイ ガーフレックスを用いた。回折条件はCu管球対陰極 (35 $\mathrm{kV}, 15 \mathrm{~mA}$ ）X線源, 走查速度 $2.0^{\circ} / \mathrm{min}$, サンプリング 幅 $0.01^{\circ}$, 走查範囲 $5 \sim 70^{\circ}$ である。

図-7,8より, 主要粘土鉱物は, スメクタイトであり, 主要な造岩鉱物は，石英であることがわかる。このこと

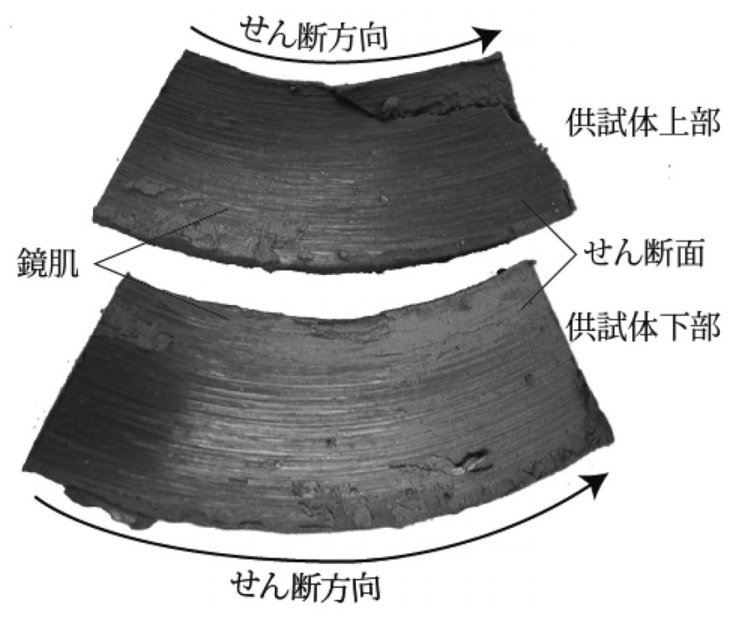

図一 6 せん断面（せん断変位 $\mathrm{D}=1000 \mathrm{~mm}$ )

Fig 6 Shear plane (shear displacement $D=1000 \mathrm{~mm}$ ) 
は，土質試験結果において，活性粘土に分類されたこと と一致する。なお，X線回折試料には，すべり面とせん 断面の表面を，厚さ $1 \mathrm{~mm}$ 程度に削り取り，自然乾燥さ せたものを用いている。

これらの結果を比較すると，すべり面，せん断面の主 要粘土鉱物および，造岩鉱物は一致している。せん断強 度を支配するスメクタイトを示す $2 \theta \doteqdot 6^{\circ}$ の回折強度が 同程度であることから, 両試料のスメクタイト含有量は, ほぼ同程度であると考えられる。このことから，リング せん断試験の供試体のせん断面が，地すべり粘土と同様 の鉱物組成を持っており，供試体のせん断面が地すべり 面を再現できていることを確認した。

\section{6. 走査性顕微鏡による微視的構造の観察}

すべり面，せん断面および，せん断面側部に関して， 走査性顕微鏡（以下，SEMと記す）を用いた観察を行っ た。試料は, 図 - 9 に示すように, $5 \mathrm{~mm}$ 四方, 厚さ $1 \mathrm{~mm}$ 程度に整形したものを, 自然乾燥させた後, 金蒸着を行った。

\section{1 粘土の構造に関して}

粘土の微視的構造は, 板状の粘土粒子が単独で存在す ることはほとんどなく，程度の差はあるものの，粒子の 凝集体によって形成されている。さらに，粘性土におけ る接触は結合水を含めた固体接触であり，ランダムな場 合でも水中に遊離して存在するとは考えられない。よっ て，この凝集体を力学的取扱いの最小単位とみなすこと ができる。

以下の議論では，松尾ら ${ }^{10)}$ の提案に基づき，表- 3 に 示すように，粘土の構造を構成する基本単位の用語とし て，凝集体についてはペッドを，その周りの間隙につい ては，ポを用いる。

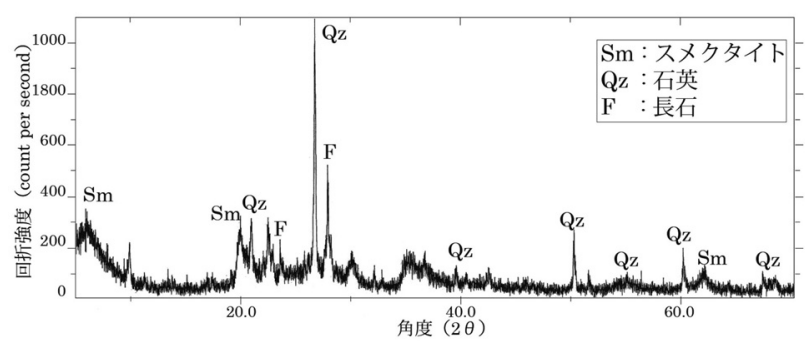

図ー 7 すべり面粘土のX線回折チャート

Fig 7 X-ray diffraction chart of slip surface clay

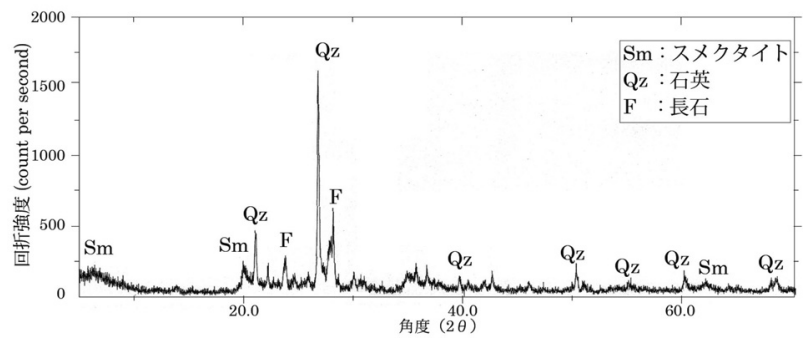

図ー8 せん断面のX線回折チャート

Fig. 8 X-ray diffraction chart of shear plane
外力によってペッドは変形もしくは細粒化し，ペッド 内の間隙（主にサブミクロポア）は，物理化学的な力の 作用の平衡に依存するものとする。ペッド間のポアの変 化は, 力学的な力の平衡に依存した, ペッドの移動, 変 形の結果であると考える。

上述した基本単位の，配列の程度を表すものとして知 られている基本モデル11) 図-10に示す。基本モデルは, 重力が下方に作用しているものとして，粒子が配列する 際の断面を示した模式図である。基本モデルは主に，単

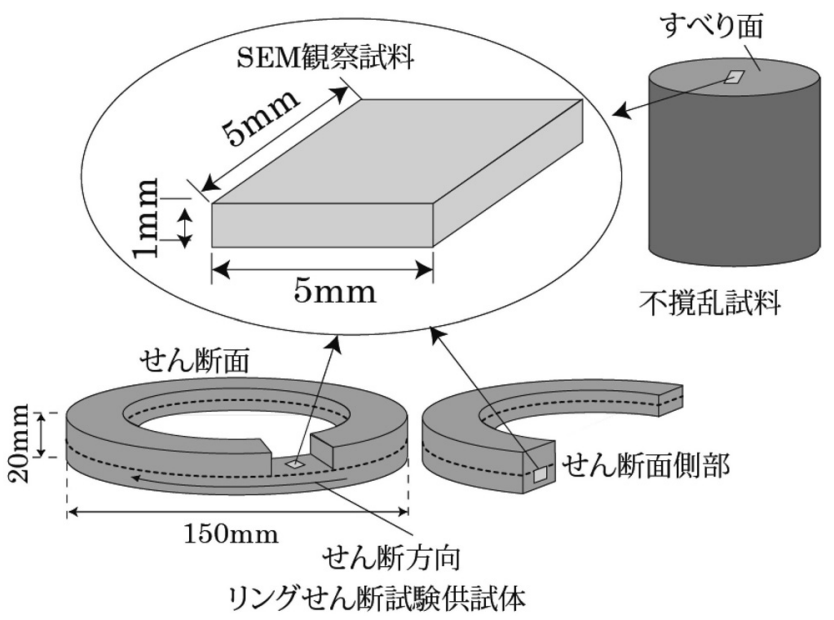

図－9 SEM観察試料作製模式図

Fig. 9 SEM observation sample preparation schematic diagram

表一 3 基本単位（ペッド，ポア）の定義 ${ }^{10)}$

Table 3 Denifinition of basic unit (ped and pore)

\begin{tabular}{cccc}
\multicolumn{2}{c}{ ペッド (ped) } & \multicolumn{2}{c}{ ポア (pore) } \\
\hline $\begin{array}{c}\text { マクロペッド } \\
\text { macro ped }\end{array}$ & $(>50 \mu \mathrm{m})$ & $\begin{array}{c}\text { マクロポア } \\
\text { macro pore }\end{array}$ & $(>10 \mu \mathrm{m})$ \\
\hline $\begin{array}{c}\text { メソペッド } \\
\text { meso ped }\end{array}$ & $(2-50 \mu \mathrm{m})$ & $\begin{array}{c}\text { メソポア } \\
\text { meso pore }\end{array}$ & $(1-10 \mu \mathrm{m})$ \\
\hline $\begin{array}{c}\text { マイクロペッド } \\
\text { micro ped }\end{array}$ & $(0.1-2 \mu \mathrm{m})$ & $\begin{array}{c}\text { マイクロポア } \\
\text { micro pore }\end{array}$ & $(0.01-1 \mu \mathrm{m})$ \\
\hline $\begin{array}{c}\text { サブマイクロペッド } \\
\text { submicro ped }\end{array}$ & $(<0.1 \mu \mathrm{m})$ & $\begin{array}{c}\text { サブマイクロポア } \\
\text { submicro pore }\end{array}$ & $(<100 \mathrm{~A})$ \\
\hline
\end{tabular}

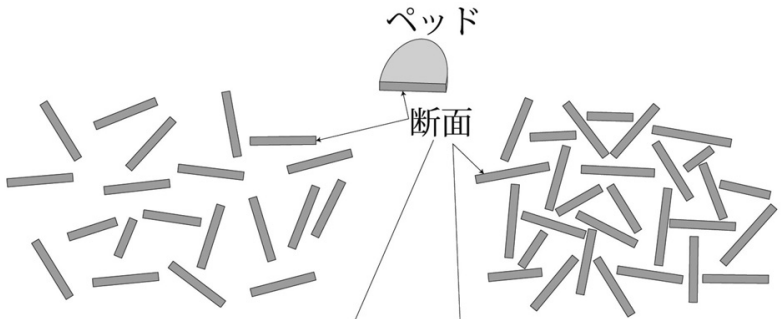

(a)ランダム構造

(b) 綿毛化構造
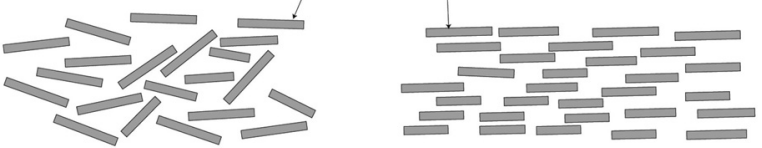

(c) 分散構造（不完全配向構造） (d) 完全配向構造

図一10 基本モデル（基本単位の配列程度 $)^{11}$ に加筆 Fig. 10 Basic model (degree sequence of basic unit) 
一種類の粘土鉱物からなる場合において提案されたもの である。自然の粘性土は，多種類の粘土鉱物やシルト分 （もしくは砂分）を含むため，基本モデルほど単純では ないが，以下では単純化して，これらの基本モデルに分 類して議論を進める。また，先述したように，粘土粒子 は単独ではなく，凝集体として存在することから，力学 的取扱いの最小単位である，ペッドの配列および配向を 表していると考える。なお，配向の定義は，構成単位と なる粒子が一定方向に配列することである。

\section{2 すべり面およびせん断面の観察}

すべり面（図－1）を50倍に拡大したものを図－11に， 2000 倍に拡大したものを図－12に，図－12において，目 視観察によって認識が可能なペッドを示したものを，図 -13に示す。また，図ー 6 に示したせん断面を,50倍に 拡大したものを図ー14に，2000倍に拡大したものを図 $15 に$, 図ー15において, 目視観察による認識が可能なペッ ドを示したものを，図ー16に示す。

図－11からは，一定方向（せん断方向）に条線が発達 しており，条線に沿った長さ500 $\mu \mathrm{m}$ 程度の亀裂を確認 できる。また，所々に $30 \mu \mathrm{m}$ 程度のペッドを確認できる。

図－12,13からは, ペッドが表面を覆い, すべり面と

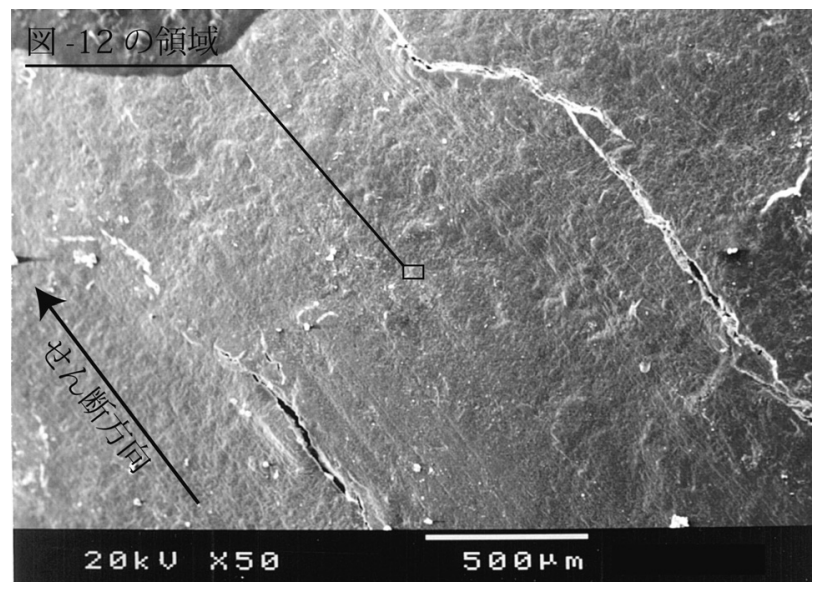

図一11 すべり面（50倍）

Fig. 11 Slip surface (50 times)

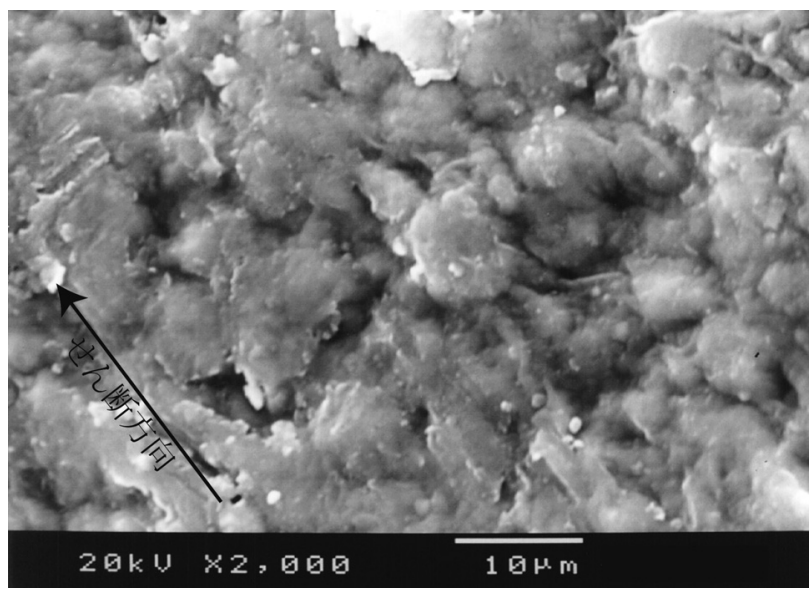

図ー12 すべり面 (2000倍)

Fig. 12 Slip surface (2000 times)
平行にペッドが配向している様子が観察できる。ペッド の大きさは, $2 \sim 10 \mu \mathrm{m}$ 程度のメゾペッドが見られ，さら に細粒化したマイクロペッドや，目視では大きさを認識 できない，サブマイクロペッド，サブマイクロペッドが 表面を覆っていることを確認できる。また，ポアに関し ては，所々に $2 \mu \mathrm{m}$ 程度のメゾポアを確認できる（図一 13中の「細粒化したペッド」は最も細粒化したペッドを 指す)。

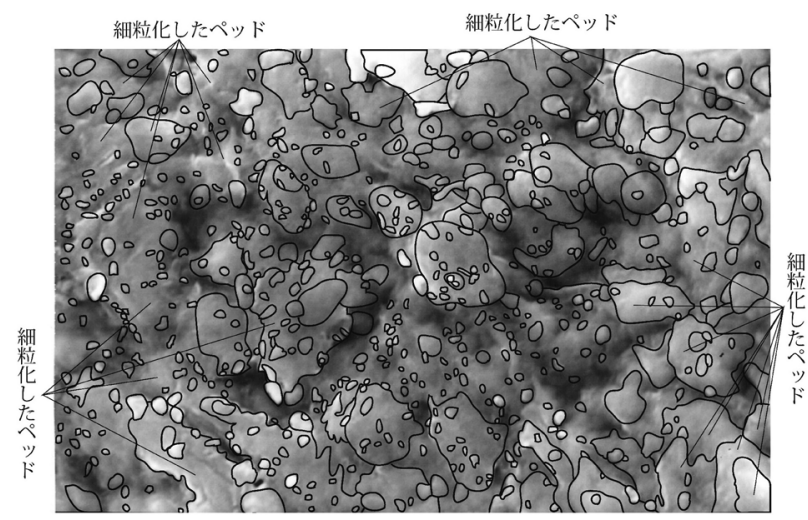

図ー13 すべり面（2000倍）のペッド

Fig. 13 Ped at slip surface (2000 times)

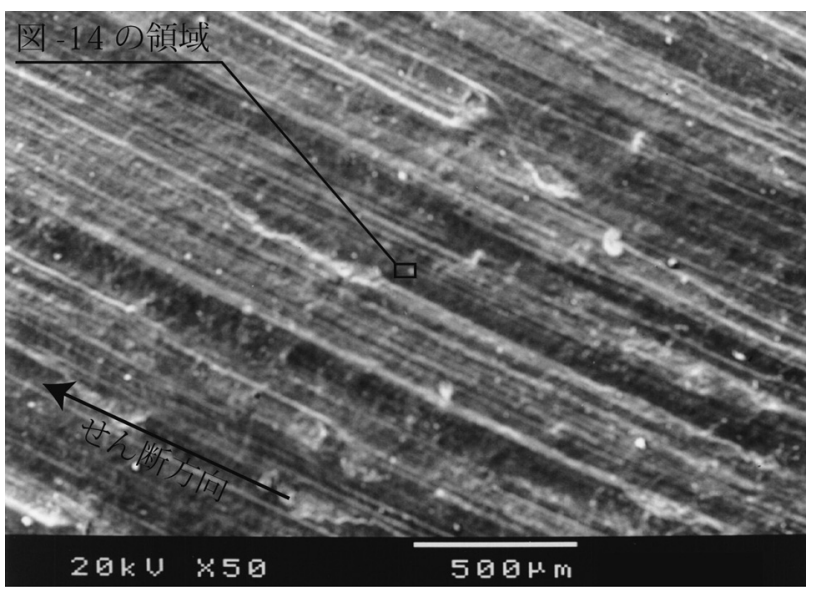

図一14 せん断面（50倍）

Fig. 14 Shear plane (50 times)

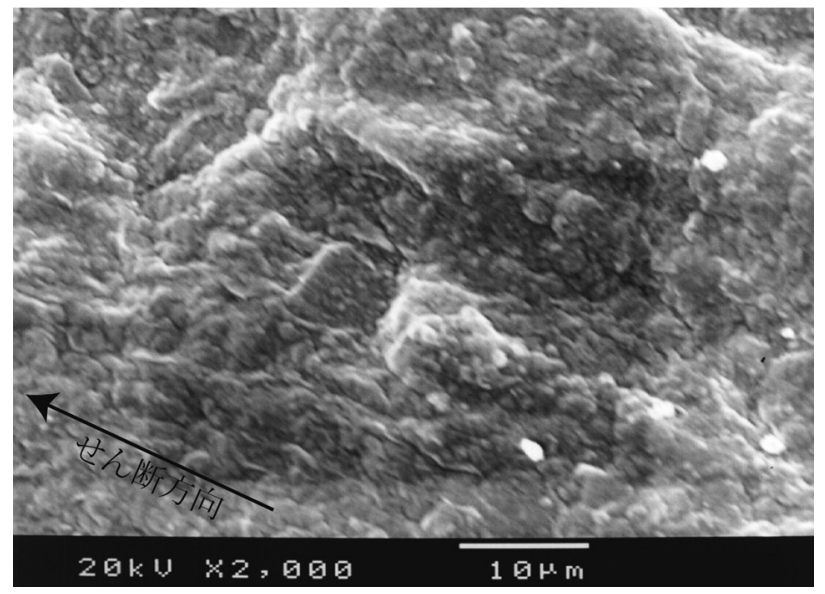

図一15 せん断面（2000倍）

Fig. 15 Shear plane (2000 times) 


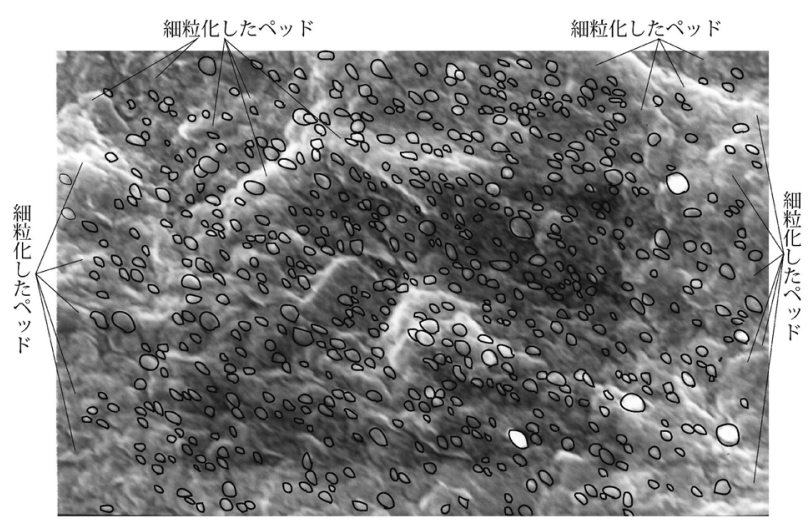

図一16 せん断面（2000倍）のペッド

Fig. 16 Ped at shear plane (2000 times)

図－14からは，せん断方向に条線が発達していること を観察できる。また，所々に $30 〜 60 \mu \mathrm{m}$ 程度のペッドを 確認できる。

図－15,16からは，ペッドが表面を覆い，せん断面と 平行にペッドが配向している様子が観察できる。ペッド の大きさは, 0.5〜2.5 $\mu \mathrm{m}$ 程度のマイクロペッド〜メゾ ペッドが見られ，すべり面と同様に，目視では大きさを 認識できない，さらに細粒化したマイクロペッド，サブ マイクロペッドが表面を覆っていることを確認できる （図－16中の「細粒化したペッド」は最も細粒化したペッ ドを指す)。また，ポアに関しては，所々に $0.5 \mu \mathrm{m}$ 程度 のマイクロポアを確認できる。50倍に拡大したすべり面 （図－11）とせん断面（図－14）を比較すると，共に， 条線の発達が見られるが，せん断面の方が，本数が多い。 また，すべり面で確認された，条線に沿った亀裂（長さ $500 \mu \mathrm{m}$ 程度）は，せん断面では確認できない。

2000倍に拡大したすべり面（図－12,13）とせん断面 （図－15,16）を比較すると，ペッドの大きさがすべり面 においては，長軸方向に $10 \mu \mathrm{m}$ 程度のものが多いのに対 して, せん断面においては, $2 \sim 3 \mu \mathrm{m}$ 程度のものが多く, 比較的小さいことがわかる。また，せん断面では，ペッ ドの長径軸が配列している方向と，せん断方向が多くの ペッドにおいて，ほぼ一致している傾向がある。一方で すべり面では，この傾向は弱くなる。また，すべり面， せん断面共に，表面は，マイクロペッドやメゾペッドが 配向しており，サブマイクロペッドが表面を覆っている ことが観察できる。

\section{3 せん断面側部の観察}

せん断面側部を 50 倍に拡大したものを図ー17に, 500 倍 に拡大したものを図ー18に,2000倍に拡大したものを図 -19に示す。

図－17において，右下部分が供試体のせん断面側部に あたる。せん断面に沿って, $80 \mu \mathrm{m}$ 程度の厚みを持った 層（以下，せん断層と記す）が生成されていることがわ かる。

このせん断面側部をさらに拡大した図－18より，せん 断層は，せん断方向と平行に，複数の扁平なペッドが重

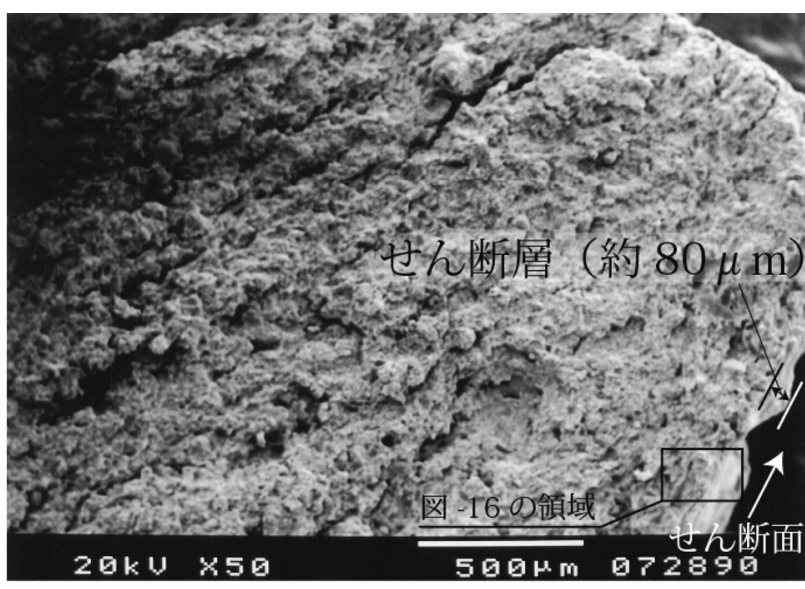

図-17 せん断面側部（50倍）

Fig. 17 Side of Shear plane (50 times)

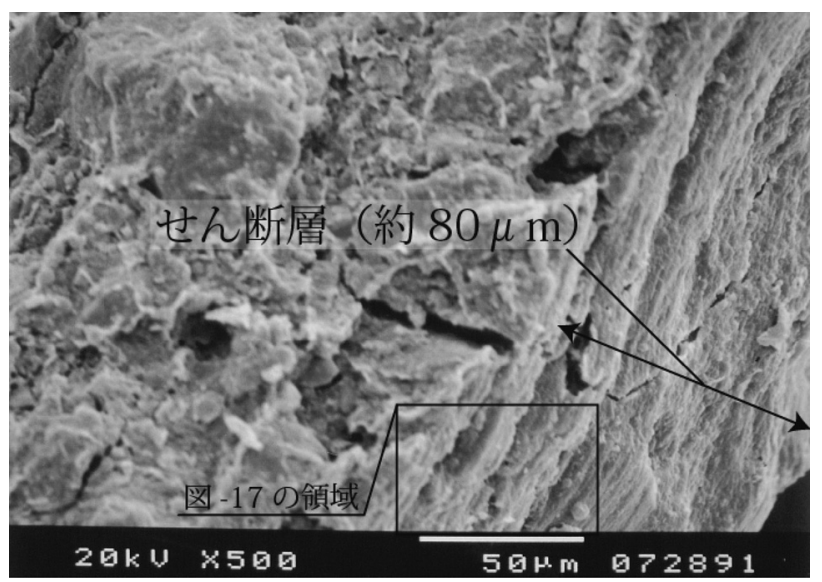

図-18 せん断面側部（500倍）

Fig. 18 Side of Shear plane (500 times)

なった状態にあることがわかる。せん断面の上下でほぼ 同様の構造が生成されると仮定すると，せん断層は，供 試体上下面合わせて, $160 \mu \mathrm{m}$ 程度の厚みを持っていると 推定される。また，せん断層の構造は，せん断方向と平 行な方向に配向した，完全配向構造であり，せん断層以 外の箇所の分散構造とは明瞭に異なる構造を持っている ことがわかる。

\section{7. 考察}

これまでにも，せん断面の構造に関する様々な研究が 行われている。代表的なものとしては，釜井ほか ${ }^{12} に に よ$ る，進行性破壊の伝播に関する観察結果や，岸本ほ か ${ }^{13), 14,15)}$ による， せん断層の構造解析と，せん断層の透 水係数が周囲と比較して大きいことを示した結果，およ

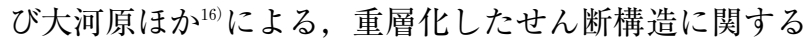
報告などが存在する。また，微視的構造に着目した先駆 的な研究として，眞弓 ${ }^{3)}$ は，残留状態に至るまでのすべ り面，およびせん断面の形成過程について考察している。 眞弓 ${ }^{3)}$ の考察の特徵は，せん断の進行に伴って，分級が 生じ，細粒分がすべり面，およびせん断面に濃集するよ うに運動すると仮定し，変形の進行に伴って，粒子が再 


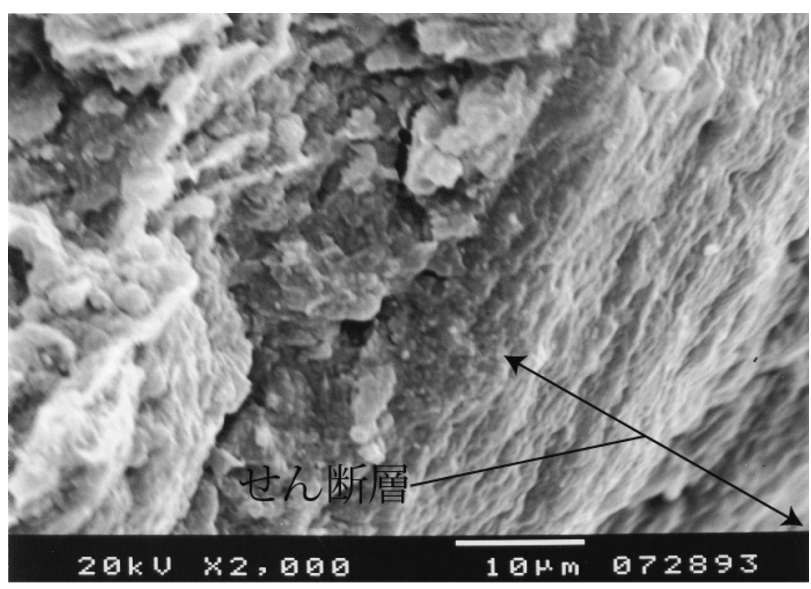

図一19 せん断面側部 (2000倍)

Fig. 19 Side of Shear plane (2000 times)

\section{配列するとしている点である。}

今回の結果からは，すべり面，およびせん断面におい て，ペッドの配向（図 $-12,13,15,16 ）$ と，せん断方向 と平行に重なりあうように配向した, $80 \mu \mathrm{m}$ 程度の厚み を持つ, せん断層（図一18）を確認している。これらは, 眞弓 ${ }^{3)}$ の示した，粒子の再配列に相当すると考えられる。 一方, すべり面, およびせん断面の表面は, メゾペッド からサブマイクロペッドまでの, 様々な大きさのペッド を確認することができることや， せん断層側部(図－18) の観察から, せん断面から離れるに従って, せん断層内 で，ペッドの大きさ大きくなるように変化する，分級の 様相を確認することはできない。

ここで, 今回の観察結果と一致するようなメカニズム として, すべり面, せん断面において, ペッドの細粒化 （破壊）という概念を導入すると, 力学的な挙動と併せ て説明することが可能である。この考察を以下に述べる。

\section{1 リングせん断試験における破壊メカニズム}

ペッドの細粒化（破壊）によって, 強度が低下すると 考えると, リングせん断試験における, せん断面付近の 微視的な構造の変化と強度の関係は図ー20に示すように, 下記の 4 ステップからなると考えることが可能である。
1. せん断開始〜完全軟化強度時：せん断の開始に伴 い,ペッドの噛み合わせによる抵抗力が増加する。 その際には，ペッドの変位および，回転を伴う。 これらの量は, 極めて微小な量であると考えられ る。

2. 完全軟化強度時：ペッドの噛み合わせ状態が，せ ん断応力が最大となる状態になり，せん断面周辺 のペッドの破壊に必要な強さが完全軟化強度とし て発現される。

3 . 完全軟化強度〜ひずみ軟化時：完全軟化強度に達 した後に，ペッドの細粒化が生じる。その後，せ ん断の進行に伴い，細粒化したペッドが再配列を はじめる。

4.ひずみ軟化〜残留強度 : せん断変位の増加に伴い, 細粒化したペッドの配列が進行し，再配向した時 点で残留強度状態となる。また, 細粒化したペッ ドが配向した，せん断層が形成される。

今回の検討では, 図 -4 中の垂直応力 $\sigma^{\prime}=200 \mathrm{kPa}$ の供 試体において, せん断変位 $\mathrm{D}=300 \mathrm{~mm}$ 程度で残留強度状 態となった後, $700 \mathrm{~mm}$ の変位（計 $1000 \mathrm{~mm}$ ）を経たせん 断面の観察を行っている。一方で，試料を採取した地す

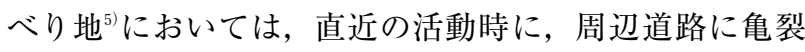
が発生し, 現場状況から $300-500 \mathrm{~mm}$ 程度の変位量が あったと推定される。さらに再滑動型地すべりであるこ とから，累積では数mに及ぶ変位も想定される。よって， 現場の状況から推察するに, せん断変位は, すべり面(図 - 1,11-13）の方が大きい可能性が高い。

上載圧に関しては，図－1のすべり面以浅の強風化泥 岩およびその上位の崩積土の単位体積重量を $17 \mathrm{kN} / \mathrm{m}^{3}$ と 仮定すると，すべり面（図-1,11-13）の上載圧は 170 $\mathrm{kPa}$ となり, せん断面（図-6,17-19）の上載圧垂直応 力 $\sigma^{\prime}=200 \mathrm{kPa} よ り$ 小さい。ここで, せん断変位は細粒 化したペッドの再配向に対して支配的であり，上載圧は ペッドの細粒化に対して支配的であると考えると，すべ り面 (図-1,11-13) のペッドの大きさが，せん断面 (図 -6,17-19）のペッドの大きさよりも若干大きいことを

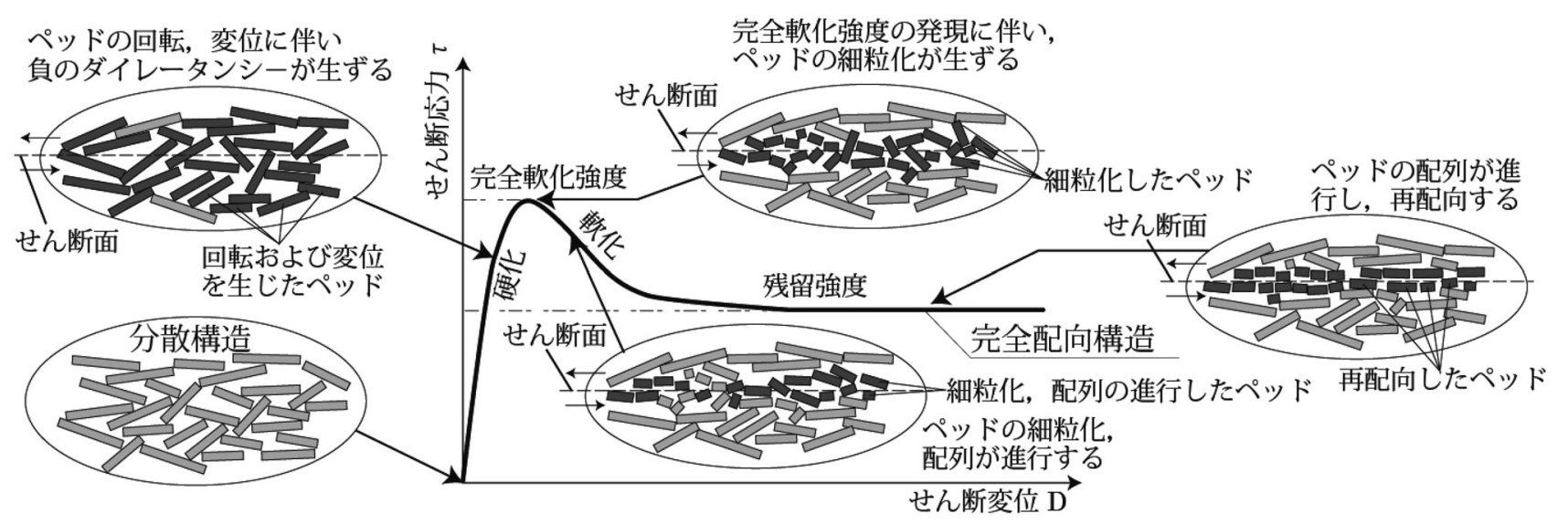

図一20 応力〜ひずみ関係と微視的構造

Fig. 20 Relationship between stress-strain curve and microscopic structure 
説明可能である。ただし，この事柄に関しては，上載圧 の異なるリングせん断試験を実施し，検証することが必 要である。

ポアに関しては，すべり面では $2 \mu \mathrm{m}$ 程度のメゾポア が存在するが，せん断面では, $0.5 \mu \mathrm{m}$ 程度のマイクロポ アとなり，間隙が小さいことがわかる。すべり面および， せん断面においては，ペッドの大きさは，ほほ均一であ り，ペッドの径が大きい状態にあるほど，ポアも大きく なる傾向が見受けられる。

上記の事柄から, 粘性土のせん断面における構造 (ペッ ドの細粒化，配列程度）と応力ーひずみ関係，および上 載圧には密接な関係がある可能性が示唆された。

\section{2 せん断層の構造}

せん断層と，それ以外の筒所における構造の差異につ いて，以下に考察する。図-18,19の目視観察より，せ ん断層は，ペッドがほぼ一定方向に配列した完全配向構 造であり, せん断層以外の箇所は, 分散構造となってい ることがわかる。供試体は，含水比 $200 \%$ のスラリーを 充分に擋拌した後に圧密を行なっているので，スラリー 状態ではランダム構造もしくは，綿毛構造であったと考 えられる。その後の予圧密によって, ペッドが幾分, 配 列した分散構造となる。せん断によって，せん断面付近 では，ペッドの微小な変位および，回転が生じるものの， 破壊までは分散構造が保たれていたと考えられる。破壊 すなわち，ペッドの細粒化後には，細粒化したペッドの 再配列が進み，分散構造から完全配向構造へと移行する と考えることができる。残留強度状態となった時点では, せん断面から一定区間（供試体においては，せん断面を 挟んで $160 \mu \mathrm{m}$ 程度）が完全配向構造となり，せん断層 が形成されたと考えられる。このことは，図－20に示す ように, 応力一せん断変位曲線の傾きの変化は, せん断 面周辺の構造の変化に伴って生ずると解釈することがで きる。ただし，今回の検討では，圧密後の供試体の構造 や，せん断に伴う微視的構造の変化を観察可能なSEM 画像等は得られておらず，残留強度状態からの推測であ る。よって，今後は，せん断の進行に伴う微視的構造の 連続的な変化を確認できるような情報を得た上で，議論 を進める必要がある。また，ペッドとポアは 3 次元の構 造を持っていることから, 粘性土の微視的構造と力学的 特性との対応を検討するには, 3 次元構造の変化に関して も検討を進める必要がある。

\section{8.おわりに}

粘土は，種々の粒径を持った粘土粒子が，過去に受け た物理化学的作用の結果として凝集し，それらが配列し た構造を持っている。これらの, 微視的な構造変化と力 学的な特性の関係性には不明なことが多い。特に，せん 断面は，強度に対して支配的であることから，せん断面 の微視的な構造変化に関する検討を行うことは，粘土の 破壊特性を把握することは勿論のこと, 弾塑性体として
の取り扱いに，微視的な構造変化の及ぼす影響を取り达 むことにも繋がると考える。しかし，これらの問題に関 して，実際の問題に適用できるような検討は，行われて いないのが現状である。よって，今後は，地すべり粘土 の生成過程や，微視的な視点からの，粘性土の破壊メ力 ニズムを解明し，巨視的（ここでは，要素試験レベルを 指す）な視点からの，力学的特性との関連を明らかにし ていく必要があると考える。

現在の粘土の構造を知ることによって，過去にその粘 土が経験した応力履歴や，今後の挙動を，ある程度推定 することが可能になると考える。今回の検討より，すべ り面粘土に执いては，粘土粒子の凝集体であるペッドの 配列が顕著であり, 配列程度から変動方向, 応力状態の 推定ができる可能性が高いことが示唆された。

特に，せん断面側部の微視的構造からはペッドの配列 状態が，完全配向状態にあれば，残留強度状態となって おり, 配列が進行中で, 完全配向状態には至らない状態 にあれば，完全軟化強度以下，残留強度以上の応力状態 にあると推定することができる。

今回の検討から，残留強度状態にあるすべり面粘土の 微視的構造の特徵がある程度明らかとなったものの，せ ん断変位の増加に伴う，ペッドの変位，回転，破壊後の ペッドの細粒化，配列等に関しては，今後，SEM画像 の画像解析等による定量評価手法を確立する必要がある 今回の検討から明らかとなった事柄を，以下に列挙する。 1.すべり面と，リングせん断試験後の，せん断面に拐 いては，共に条線が見られ，表面のペッドは，配向 している。しかし，条線の数に差異が認められる。

2. 残留強度状態にあるせん断面周辺を，側部から観察 すると，せん断面と平行な方向にペッドが配向した 構造を持つ。配向したペッドは，複数の薄層が重な り合う構造を持ち, $1000 \mathrm{~mm}$ のせん断変位によって, せん断面を挟んで $160 \mu \mathrm{m}$ 程度の厚みを持つ，せん 断層を形成している。

3.せん断層は，周辺の分散構造とは明瞭に異なる完全 配向構造を持ち，せん断層以外の箇所と比較して， ペッドは細粒化している。また，細粒化したペッド は一定方向に再配列しており，完全配向状態にある。

4. 残留強度状態におけるペッドの細粒化の程度の違い は，上載圧掞よび，せん断変位の影響によると考え られる。

5.リングせん断試験における供試体は，予圧密によっ てペッドが幾分，配列した分散構造にあり，せん断 層以外では，大きな構造変化は生じていない。一方 で，せん断層のペッドは細粒化し，せん断面と平行 に配向している。

6. せん断変位に伴う, せん断強度の変化は, 微視的構 造の変化と密接な関係があると考えられる。完全軟 化強度が発現されるまでは，ペッドの変位および， 回転による，噛み合わせの強化によって，せん断応 
力が増加する。破壊後は，ペッドの細粒化および， 再配列の進行に伴ってせん断応力は低下する。最終 的には，配列が完了し，完全配向状態となった段階 で，残留強度状態に収束する。

7. 粘性土においては, せん断変位の増加に伴って, 力 学的な取扱いをする際の上限単位となるペッドの大 きさが，破壊の前後で変化すると考えられる。

\section{謝 辞}

査読者の方からは，非常に有益かつ貴重なご指摘を頂 いた。SEM画像の撮影には, 富山県立山カルデラ博物 館の機器を使用させて頂いた。ここに記して感謝する。

\section{引用文献}

1) 地すべりに関する地形地質用語委員会編（2004）：地すべり地 形地質的認識と用語, 日本地すべり学会, pp. 84-85.

2 ）守随治雄（1999）：結晶片岩地すべり地における地質と強度特 性の関係について とくに善德地すべり深礎杭掘削面を観察 して, こうえいフォーラム, No. 8, pp. 21-35.

3 ) 眞弓孝之（2004）：すべり面せん断試験機の開発とその適用に よるすべり面せん断抵抗角の評価, 佐賀大学学位論文.

4 ）日本地すべり学会（2013）：すべり面一地質的特徵と構造・物 性一, 日本地すべり学会.
5 ）村尾英彦，䟠谷達也（2003）：地すべり面付近の試料を用いた リングせん断試験による残留強度定数, 地すべり, Vol. 41, No. 4 , pp. $71-76$.

6 ) Bishop, A. W., Green, G. E. et al.(1971) : A New Ring Shear Apparatus and its Application to the Measurement of Residual Strength, Geotechnique, Vol. 21, No. 4, pp. 273-328.

7 ）村尾英彦, 渋谷達也（2003）：リングせん断試験による地すべ り面強度定数決定のための試験条件に関する検討, 第38回地 盤工学研究発表会発表講演集, pp. 227-228.

8 ) Skempton, A. W.(1970) : First-time Slide in Overconsolidated Clays, Technical Notes, Geotechnique, Vol. 20, No. 3, pp. $320-324$.

9 ）社団法人土木学会（1992）：X線粉末回折による鉱物の同定, 軟岩の調査・試験の指針 (案), pp. 142 .

10）松尾新一郎，嘉門雅史（1976）：粘土の構造に関する用語につ いて，土と基礎，Vol. 24, No.1,pp. 59-64.

11) Yong, R. N. and Warkentin, B. P.(1966) : Introduction to Soil Behavior, Macmillan.

12）釜井俊孝，宮田雄一郎（1993）：地すべり粘性土のいち面せん 断における破壊の伝播過程，地すべり，Vol. 29, No.4, pp.917.

13）岸本良次郎（1994）：土の一面せん断試験により得られた剪断 層の構造，地すべり, Vol.31, No.1, pp. 10-20.

14）岸本良次郎, 吉田純（1997）：土のせん断の進行にともなう剪 断層構造の変化, 地すべり, Vol. 34, No. 1, pp. 8-14.

15）岸本良次郎（1997）：含水比による剪断層構造の変化およびせ 几断層の透水性，地すべり，Vol. 34, No. 2, pp. 1-8. （原稿受付2013年 4 月15日，原稿受理2015年 1 月15日） 